\title{
Do wine tourists care about the labourer?
}

\begin{tabular}{|c|c|}
\hline \multicolumn{2}{|c|}{$\begin{array}{l}\text { Authors: } \\
\text { Andrea Saayman }{ }^{1} \text { (1) } \\
\text { Melville Saayman }{ }^{2}\end{array}$} \\
\hline \multicolumn{2}{|c|}{$\begin{array}{l}\text { Affiliations: } \\
{ }^{1} \text { School of Economics, } \\
\text { Faculty of Economic and } \\
\text { Management Sciences, } \\
\text { North-West University, } \\
\text { Potchefstroom, South Africa }\end{array}$} \\
\hline \multicolumn{2}{|c|}{$\begin{array}{l}{ }^{2} \text { Tourism Research in } \\
\text { Economics, Environs and } \\
\text { Society (TREES), Faculty of } \\
\text { Economic and Management } \\
\text { Sciences, North-West } \\
\text { University, Potchefstroom, } \\
\text { South Africa }\end{array}$} \\
\hline \multicolumn{2}{|c|}{$\begin{array}{l}\text { Corresponding author: } \\
\text { Andrea Saayman, } \\
\text { andrea.saayman@nwu.ac.za }\end{array}$} \\
\hline \multicolumn{2}{|c|}{$\begin{array}{l}\text { Dates: } \\
\text { Received: } 22 \text { May } 2018 \\
\text { Accepted: } 01 \text { Nov. } 2018 \\
\text { Published: } 27 \text { Mar. } 2019\end{array}$} \\
\hline \multicolumn{2}{|c|}{$\begin{array}{l}\text { How to cite this article: } \\
\text { Saayman, A. \& Saayman, M., } \\
\text { 2019, 'Do wine tourists care } \\
\text { about the labourer?', South } \\
\text { African Journal of Economic } \\
\text { and Management Sciences } \\
\text { 22(1), a2477. https://doi.org/ } \\
\text { 10.4102/sajems.v22i1.2477 }\end{array}$} \\
\hline \multicolumn{2}{|c|}{$\begin{array}{l}\text { Copyright: } \\
\text { (C) 2019. The Authors. } \\
\text { Licensee: AOSIS. This work } \\
\text { is licensed under the } \\
\text { Creative Commons } \\
\text { Attribution License. }\end{array}$} \\
\hline \multicolumn{2}{|c|}{ Read online: } \\
\hline 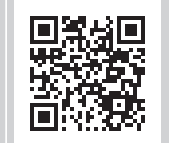 & $\begin{array}{l}\text { Scan this QR } \\
\text { code with your } \\
\text { smart phone or } \\
\text { mobile device } \\
\text { to read online. }\end{array}$ \\
\hline
\end{tabular}

Background: Consumers worldwide have recently become more aware that their consumption preferences and habits influence not only the environment, but also other people's lives. These 'ethical' consumers are therefore said to consider the moral features of the product or service in their consumption decision. The most prominent ethical consumption label is the Fair Trade label, which was established to enhance the living and working conditions of those working on small-scale farm cooperatives in developing countries.

Aim: This paper aims to determine wine tourists' willingness to pay (WTP) for improved working and living conditions for wine farm workers.

Setting: The research was conducted at the largest wine festival in South Africa, the Wacky Wine Festival in Robertson in the Western Cape, an area renowned for its wine and fruit products.

Method: The concept of a socially acceptable logo on the wine bottle - signalling fair wages to the farm workers - was assessed by using a double-bounded contingent valuation approach. Wine tourists completed 397 questionnaires during the festival in June 2017.

Results: The results indicate that $80 \%$ of wine tourists are willing to pay more for socially responsible wines. The responsible wine consumer is typically younger and a premium of R11 per bottle of wine would be accepted if it signals fair treatment of workers.

Conclusion: The socially responsible wine tourist in South Africa is more concerned about quality and the moral implications of the wine than the price. There is support for the implementation of a socially responsible label for wine products.

Keywords: Wine tourism; ethical consumption; contingent valuation; Wacky Wine Festival.

\section{Introduction}

A key trend in the tourism industry is a change in consumer behaviour, and one of the attributes of the new tourist is ethical consumption, which is becoming increasingly important (Saayman 2017). Doane (2001) defines ethical consumption as the purchase of a product or service that concerns a certain ethical issue, such as human rights, labour conditions, environmental friendliness and wellbeing - to name just a few - which is chosen freely by an individual consumer. Ethical consumption includes products that benefit the natural environment (such as items made from legally logged wood and products that promote animal health) and products that benefit people (such as items free from child labour and unsafe working conditions) (De Pelsmacker, Driessen \& Rayp 2005:363). De Pelsmacker et al. (2005:364) also note that consumers can translate their ethical concerns into supporting, and therefore buying, certain products for their positive qualities (e.g. environmentally friendly products), or boycotting products for their negative qualities (e.g. those made by child labourers), or both.

Most research shows that ethical consumption is growing (Hines \& Ames 2000). Research conducted in Europe showed that $46 \%$ of European consumers were willing to pay substantially more for ethical products (Market \& Opinion Research International 2000). The value of organic food and drinks globally was estimated at US\$30 billion in 2005. In the US alone, this sector was valued at US\$14.5 billion and in Europe at US\$14.4 billion in the same year (Didier \& Lucie 2008:479). The global market for fair trade products was valued at US\$900 million in 2005 , with an estimated growth rate of $20 \%$ per annum (Wright \& McCrea 2007). Arnot, Boxall and Cash (2006:555) also indicate that fair trade products represent a large and growing market in countries such as Canada and the UK. From a tourism point of view it is therefore paramount that the industry at large take note of these changes in behaviour, since it can have far-reaching implications if these changes in purchasing behaviour are ignored or not addressed. 
Bird and Hughes (1997) identify three types of ethical consumer and highlight the complexity of this market:

- Consumers who are primarily motivated by moral values.

- Consumers who are primarily motivated by brand names and quality, for whom the 'ethicalness' of the product is an added bonus.

- Consumers who are selfish and cannot easily be persuaded to buy ethical goods, since their buying behaviour is primarily driven by price and traditional quality concerns.

Most of the research on ethical consumption focuses on fair trade products and on consumers' willingness to pay (WTP) for fair trade as opposed to traditional products (see Arnot et al. 2006; Basu \& Hicks 2008; De Pelsmacker et al. 2005; Van den Broeck et al. 2017, to name a few). Very few studies specifically address the working and living conditions of workers and even fewer studies have been conducted in the field of wine tourism and consumption. Hence this article, which investigates wine tourists' WTP for improved working and living conditions for wine farm workers. The research was motivated by a series of strike actions in the region of Robertson in the Western Cape province of South Africa during 2016. Wine farmer workers downed tools and went on strike to secure better living and working conditions. The strike went on for 3 months before a settlement was reached.

Well known for its wine and fruit production, the area has been called the 'valley of vines and roses' (Wines of South Africa 2018). It is located along Route 62, the longest wine route in South Africa, with 48 wine cellars and estates forming part of the Robertson wine region (Kavonic 2017). The region traditionally produces some of the best white wines in the country, thanks to its high summer temperatures and cooling winds that blow through the valley (Wines of South Africa 2018). In addition, the Robertson valley plays host to the largest wine festival in the country. Therefore tourism, and especially wine tourism, plays a very important role in the local economy, which raises the question: would wine tourists be willing to pay more for a bottle of wine in order to secure better living and working conditions for wine farm workers? In other words, how ethical are wine tourists in their consumption behaviour?

\section{Literature review}

As noted above, most of the research available on ethical products analyses fair trade products. This section therefore focuses on fair trade, with the notion that other ethical consumption labels and products could build on the fair trade concept. This is supported by Shaw and Clark (1999), who conducted a qualitative study in the UK and found that fair trade was the most important issue of ethical concern in consumer behaviour.

Fair trade has a long history, since it was established in the 1950s as an alternative trade concept (Steinrücken \& Jaenichen 2007). It is defined as a trading partnership based on dialogue, transparency and respect, which seeks greater equity in international trade. It contributes to sustainable development by offering better trading conditions to, and securing the rights of, marginalised producers and workers, especially in the southern hemisphere (World Fair Trade Organization 2017a). In plain language, fair trade aims to ensure that the benefits of trade reach smallholder producers in low-income countries (Fairtrade Labelling Organizations International 2017). Fair trade includes requirements on production practices, working conditions, labour remuneration, environmental management and social policies (Van den Broeck et al. 2017). It therefore takes social and environmental issues into consideration when products are imported from developing countries (Loureiro \& Lotade 2005:130).

The goals of fair trade are to (Moore 2004:74; Redfern \& Snedker 2002:11):

- Improve the income and living conditions of producers.

- Create opportunities for women and indigenous people while protecting children from exploitation.

- Raise awareness among international consumers about the negative effects that international trade may have on less developed countries.

- Set an example for other agents in international trade.

- Change the rules of international trade.

- Protect the rights of people in less developed countries.

These goals are based on the 10 principles of fair trade (World Fair Trade Organization 2017b):

- Creating opportunities for disadvantaged producers.

- Transparency in management and accountability to stakeholders.

- Fair trading practices that are not at the expense of small producers.

- Fair payment that entails fair prices and fair wages, which are at least the local living wage.

- No child or forced labour practices.

- A commitment to non-discrimination, equality, women economic empowerment and freedom of association.

- Good working conditions.

- Provision of capacity building to improve development.

- Raising awareness of the aims of fair trade.

- Respect for the environment to ensure sustainability.

The effectiveness of the fair trade movement has been questioned: would consumers really pay more for a product with the fair trade label? A number of studies have been conducted to answer this question and they reveal the following: Elliott and Freeman (2003) found that $80 \%$ of US consumers polled in interviews said they would not pay more for products because they were produced in good living and working conditions. A study conducted in 1999 found that $76 \%$ of respondents were willing to pay an additional US\$5 on a US\$20 product that was free of sweatshop labour (Program on International Policy Attitudes 2000). Hicks (2006) found that respondents were willing to pay more for fair trade coffee as opposed to other coffees. A study conducted by the European Union found that $93 \%$ of consumers who had 
already bought fair trade products would be prepared to buy these products at an equal price, and $70 \%$ were willing to pay at least $10 \%$ on top of the standard price for the product. Basu and Hicks (2008) and Loureiro and Lotade (2005) found similar results. De Pelsmacker et al. (2005) also found that the fair trade label was the third most important attribute in coffee, after brand and flavour.

A number of research articles have also investigated whether ethical consumers have certain characteristics that distinguish them from other consumers. The research by De Pelsmacker et al. (2005) used cluster analysis and identified four clusters of consumers. They found that $11 \%$ of their research population were considered 'fair trade lovers', and together with the 'fair trade likers' - who were the biggest cluster they made up $50 \%$ of the total population. The 'fair trade lovers' were predominantly in the 31-45 age category, and although they did not differ much demographically from respondents in other clusters, they were more idealistic. This research confirms the results of Littrell and Dickson (1999), who found that consumers of fair trade products were demographically quite homogenous - they were educated and well off, with a high percentage of females in their forties. This is further supported by an Idea Consult (2002) study, which also concluded that Belgian fair trade consumers were highly educated and enjoyed higher incomes and social status than others.

Contrary to the above, Anderson and Cunningham (1972) found that younger consumers were more socially conscious and that income was of little relevance. Age, income and employment status could not be verified to distinguish socially conscious consumers in research by Dickson (2001). Roberts (1995) found that the ethical consumer was female and in her forties, but, contrary to the research by Littrell and Dickson (1999) and Idea Consult (2002), they had slightly lower incomes. This is also contrary to other studies conducted before 1995, which found that gender was not an important determinant of ethical consumption (see Sikula \& Costa 1994; Tsalikis \& Ortiz-Buonafina 1990). Additionally, Basu and Hicks (2008) showed that nationality played a role, since German respondents were more inequality averse than their US counterparts.

Besides the demographic differences identified above, the values of consumers also play an important role in ethical consumer behaviour, in the form of enduring beliefs that a given behaviour or outcome is desirable (De Pelsmacker et al. 2005). Dickson (2001) defines values as abstract principles that reflect an individual's self-concept. Several researchers found that the values of people behaving unethically were significantly different from those who behaved ethically (see Cowe \& Williams 2000; Fritzsche 1995). Values can also be seen as part of a person's personality system and as determining specific attitudes. One aspect, however, that has not been evaluated much in the literature on this topic is behavioural issues, and this research therefore included behavioural variables in order to determine whether they influenced WTP for improved working and living conditions for wine farm workers.

Various ethical buying behaviour models have been proposed; however, according to De Pelsmacker and Janssens (2007), two models stand out. Firstly, Hunt and Vitell $(1986,1993)$ proposed a model presenting various philosophical frameworks that underlie a decision-maker's ethical judgement. In their model, two ethical evaluations might occur, namely deontological and teleological evaluation. Deontological evaluation occurs when the consumer attempts to evaluate the inherent rightness or wrongness of different alternatives. Teleological evaluation implies that consumers base their assessment on how much good and bad will result from the alternatives. Vitell, Singhapakdi and Thomas (2001) showed that the deontological approach - less concerned about consequences - is a more critical or significant factor than perceptions of consequences (teleological) for ethical judgements, intentions and behaviour.

The second model was proposed by Shaw and Clark (1999). At the core of this model is the beliefs-attitude-behaviour logic. Besides concern about the issue at hand, the extent to which consumers were concerned that their personal action would contribute to a positive or negative outcome was added as a variable that determines intentions and behaviour. The latter is also referred to as perceived behavioural control. Therefore, both negative and positive attitudes had a significant impact on buying behaviour and intentions (De Pelsmacker \& Janssens 2007; Shaw \& Shui 2002). From the above it is clear that when it comes to ethical buying behaviour, both positive and negative aspects should be considered.

\section{The case study background}

In 1952, the Dutch East India Company (VOC) sent three ships to the Cape of Good Hope to start a trading post that could supply fresh produce to ships on their route between Holland and the East. The officials and workers experimented with a number of different crops, fruit and vegetables, but production was insufficient to meet the demand. Nine of the company servants were released to start farming as free settlers on the land in proximity to the fort and with the arrival of 160 French Huguenots in 1688, production finally reached satisfactory levels (Fourie 2014). With some of the French Huguenots from wine regions in France, it is not surprising that wine production was established in the Cape from 1700 to 1773 (Fourie \& Von Fintel 2014). Fourie and Von Fintel (2011) show that income inequality already existed during these early years of colonisation in South Africa, and there was a marked division between the 'wine making elite' and the other farmers, who became impoverished. And then there were the slaves.

Although South Africa is a water-scarce country with only $3 \%$ of its soil classified as fertile land, agriculture contributes almost $3 \%$ to the gross domestic product (GDP) of the country 
(a declining share) and is a large source of employment (Goldblatt 2010). An agricultural minimum wage was first introduced in South Africa in 2003 and resulted in a decline in the employment of seasonal workers, although permanent employment increased. The first unrest after the 2003 minimum wages occurred in the De Doorns wine area when workers demanded a more than $100 \%$ increase in wages. This led to a revision of the minimum wage for agricultural workers in 2013 and although the workers did not get the more than $100 \%$ increase they demanded, the minimum wage increased by more than $50 \%$. This time the wage increase led to a significant decrease in permanent employment (not seasonal employment) on farms in the country (Bureau for Food and Agricultural Policy 2015).

The 2016 labour unrest in the Robertson wine area therefore comes after the minimum wage of farm workers was increased in 2013.

\section{Method}

In order to derive non-market values for environmentally friendly or other ethical consumption goods, either revealed preferences or stated preferences can be assessed. Revealed preference methods entail the observation of the actions of consumers, for example their purchasing behaviour of ecolabel goods compared to other goods. On the other hand, stated preference methods are more often used when the value of a certain attribute cannot be directly observed and respondents have to indicate the value they attach to it (Tietenberg \& Lewis 2012). In the fair trade and ethical consumption literature, both revealed and stated preference methods have been used. Arnot et al. (2006), for example, used a revealed preference analysis to derive the value of the fair trade label on coffee. Stated preference methods are, however, much more popular and have been used by, among others, De Pelsmacker et al. (2005), Loureiro and Lotade (2005), Basu and Hicks (2008) and Didier and Lucie (2008).

There are various ways to derive stated preferences and the methods can be divided into direct and indirect. Contingent valuation is the direct method. Indirect methods include attribute-based models, conjoint analysis, choice experiments and contingent ranking (Tietenberg \& Lewis 2012). The researchers on fair trade coffee have used a variety of direct and indirect valuation methods. For example, De Pelsmacker et al. (2005) used conjoint analysis, while Basu and Hicks (2008) used a choice experiment. Contingent valuation normally entails a survey in which respondents are asked how much they are willing to pay for a certain attribute or outcome (Harris \& Roach 2009).

Alternatives are available to ascertain respondents' WTP (Makumbirofa \& Saayman, 2017), namely:

- Open-ended questions.

- Dichotomous choice.

- Payment cards.
Loureiro and Lotade (2005) used payment cards to elicit WTP for fair trade coffee, while Didier and Lucie (2008) used an experimental design and the Becker-DeGroot-Marschak mechanism to derive respondents' WTP for organic and fair trade products.

Given that no 'fair labour practices' label yet exists, for this research we used stated preference valuation and, more specifically, contingent valuation. We employed the contingent valuation method, dichotomous choice, which according to Lopez-Feldman (2012:3) is the most efficient of the three alternative methods. More specifically, we used a double dichotomous valuation question, where a bid amount was given that varied randomly across the different respondents. The respondents were then asked a follow-up bid, based on their answer to the first bid. If their answer was no to the first bid, a lower bid amount was offered, while a higher bid amount was offered if the initial bid had been accepted (Lopez-Feldman 2012).

Each respondent's reply could therefore be one of four possibilities, namely no-no, no-yes, yes-no or no-no. The initial bid amounts offered to respondents were a premium of (1) R5 (€0.33), (2) R10 (€0.66) or (3) R15 (€1) on every bottle of wine. The upper and lower bids were in R5 denominations, except for the initial R5 bid, for which the lower bid was $\mathrm{R} 2.50$. The question posed to respondents was:

Robertson was in the news last year due to strike actions by farm workers who felt that they did not receive a fair wage. Internationally the 'Fair trade' logo serves as proof that suppliers in poor countries receive a fair price for their produce. If a similar logo is developed for wine producers that pay their labourers fair wages, and this logo appears on the bottle, would you be willing to pay Rx more for the bottle of wine?

In line with previous research, we controlled for the sociodemographic characteristics of respondents, including gender, age, income and province of origin. Respondents were also asked to indicate their assessment of the price and quality of Robertson wines on a 3-point scale (cheap, the same and more expensive for price; and lower, the same and better for quality), allowing us to control for the subjective evaluation of the price and quality of the wine. In addition, we controlled for wine consumption behaviour, since respondents were asked to indicate the regularity of wine consumption on the following scale: daily, more than once a week, weekly and occasionally. The probit and doubled procedure in STATA 14 were used to analyse the data and estimate WTP.

The questionnaire was administered in 2017 by trained field workers during the Wacky Wine Festival, which is held annually in June in the Robertson valley. Altogether 397 completed questionnaires were received. With 11130 wine festival tickets sold, the sample size represents a 5\% margin of error (95\% confidence interval).

\section{Results}

The sample reveals the following: 214 (or 53.9\%) of the respondents are female, while the average age of respondents 
is 39.6 years. The average respondent earns between R300 000 and R550 000 per year, making them middleincome earners. The respondents are mainly from the Western Cape province (76.8\%), with $13.9 \%$ of respondents from Gauteng, the province that boasts the highest income per capita in South Africa. Almost 50\% of respondents find wine from the Robertson valley to be cheaper than wines from other regions in South Africa and only $8.3 \%$ think it is more expensive. By contrast, $50.8 \%$ assess the wine to be of better quality than wines from other regions, with only $7 \%$ finding it of inferior quality. The festival-goers are also keen wine consumers with $24.1 \%$ consuming wine daily and $52.7 \%$ consuming it once or more than once a week (although not daily).

TABLE 1: Responses to bids offered.

\begin{tabular}{lcccccc}
\hline Bid & R2.50(\%) & R5 (\%) & R10(\%) & R15(\%) & R20(\%) & Total(\%) \\
\hline Initial bid & & & & & & \\
No & - & 38.35 & 45.24 & 48.03 & - & 43.78 \\
Yes & - & 61.65 & 54.76 & 51.97 & - & 56.22 \\
Second bid & & & & & & \\
No & 50.98 & 49.12 & 48.25 & 63.77 & 40.9 & 50.26 \\
Yes & 49.02 & 50.88 & 51.75 & 36.23 & 59.09 & 49.74 \\
\hline
\end{tabular}

TABLE 2: Probit model estimates.

\begin{tabular}{lcccccc}
\hline Variable & \multicolumn{2}{c}{$\mathbf{1}$} & & \multicolumn{2}{c}{$\mathbf{2}$} \\
\cline { 2 - 3 } \cline { 5 - 6 } & Coefficient & $\begin{array}{c}\text { Standard } \\
\text { error }\end{array}$ & & Coefficient & $\begin{array}{c}\text { Standard } \\
\text { error }\end{array}$ \\
\hline Initial bid & -0.0247 & 0.0157 & & -0.0250 & 0.0166 \\
Female & - & - & & -0.159 & 0.136 \\
Western Cape & - & - & & 0.275 & 0.237 \\
Gauteng & - & - & & $0.710^{* *}$ & 0.291 \\
Similar quality & - & - & & $-0.334^{* *}$ & 0.140 \\
Consumed more than once a week & - & - & & 0.153 & 0.165 \\
Constant & $0.403^{*}$ & 0.169 & & 0.292 & 0.295 \\
$N$ & 386 & - & & 360 & - \\
\hline$*, p<0.1 ; * *, p<0.05$. & & & & &
\end{tabular}

In terms of their responses to the initial and follow-up bid amounts offered to them, Table 1 shows that $56.22 \%$ of all respondents were willing to pay the initial bid amount. As expected, higher initial bids were less accepted than lower initial bids (i.e. $61.65 \%$ accepted R5 compared to $51.97 \%$ who accepted R15). In terms of the follow-up bids, almost half of the respondents accepted the follow-up amount offered, either lower or higher depending on their answer to the initial bid. While quite a large percentage accepted the initial bid of R10, the higher follow-up of R15 was the least accepted. Interestingly, the higher bid from the initial R15 bid (i.e. R20) was accepted by $59.09 \%$ of the respondents to whom this bid was shown. Only $19.69 \%$ of respondents did not accept any bids offered to them.

Taking just the initial bid into consideration, a probit model was estimated. The first column of Table 2 reports the simplest model where the initial bid amount is the only independent variable. Given the estimates in Table 2, the WTP amount based on the initial estimate is R16.28. Using a general to specific approach, the various control variables were included in the model. Only very few turned out to be significant and the reduced model is shown in column 2 . It is evident that only two variables are significant: the control variable for festival-goers from Gauteng (a positive sign) and the control for quality, which indicates that those who rate the quality of the Robertson wines as similar to those of other regions in South Africa are less willing to pay. The estimated WTP, given these control variables, is close to that in the simple model, at R16.43.

The estimates in Table 2 only take the initial amount offered to the respondents into consideration and not the follow-up. The double-bounded estimates take both amounts into consideration and the results are shown in Table 3.

TABLE 3: Double-bounded estimates.

\begin{tabular}{|c|c|c|c|c|c|c|}
\hline \multirow[t]{2}{*}{ Variable } & \multicolumn{2}{|c|}{1} & \multicolumn{2}{|c|}{2} & \multicolumn{2}{|c|}{3} \\
\hline & Coefficient & Standard error & Coefficient & Standard error & Coefficient & Standard error \\
\hline \multicolumn{7}{|l|}{ Beta } \\
\hline Female & - & - & -0.618 & 1.149 & - & - \\
\hline Age 2 (24-39 years) & - & - & -0.337 & 1.689 & - & - \\
\hline Age 3 (40-49 years) & - & - & -1.418 & 2.025 & - & - \\
\hline Age 4 (> 50 years) & - & - & $-3.038 *$ & 1.844 & $-2.736 * *$ & 1.069 \\
\hline Income & - & - & 0.553 & 1.406 & - & - \\
\hline Income squared & - & - & -0.0963 & 0.171 & - & - \\
\hline Western Cape & - & - & 1.536 & 2.068 & - & - \\
\hline Gauteng & - & - & $4.157^{*}$ & 2.397 & 1.690 & 1.349 \\
\hline Cheaper price & - & - & 1.243 & 1.766 & - & - \\
\hline Same price & - & - & 1.052 & 1.735 & - & - \\
\hline Better quality & - & - & -0.349 & 1.705 & - & - \\
\hline Similar quality & - & - & $-2.868 *$ & 1.625 & $-2.113 * *$ & 0.993 \\
\hline Consumed daily & - & - & $3.067 * *$ & 1.495 & $1.985^{*}$ & 1.140 \\
\hline Consumed weekly & - & - & 1.334 & 1.365 & - & - \\
\hline Consumed more than once a week & - & - & 2.215 & 1.552 & 1.837 & 1.243 \\
\hline Constant & $11.04 * * *$ & 0.445 & $9.253^{* *}$ & 3.641 & $11.65 * * *$ & 0.828 \\
\hline Sigma & - & - & - & - & - & - \\
\hline Constant & $8.111 * * *$ & 0.439 & $8.157 * * *$ & 0.549 & $7.898 * * *$ & 0.480 \\
\hline$N$ & 386 & - & 264 & - & 308 & - \\
\hline
\end{tabular}

$*, p<0.1 ; * *, p<0.05 ; * * *, p<0.01$. 
Three models were estimated, the first being the simplest model with only the bid amounts offered. Since a general to specific approach was again followed, model 2 (column 2 ) is the model that contains all the control variables. As was the case with the probit model estimates, very few of the control variables proved to be significant and therefore a reduced model was estimated (column 3).

How willing festivalgoers were to pay for fair labour practices in Robertson can also be determined with the model estimates. For the first model, the WTP amount is the beta intercept, R11.04. Since many of the variables in the second model are insignificant, the WTP for the third model is determined instead and, accordingly, the WTP for fair labour practices is calculated at R11.05.

The results above show that ethical wine tourists in South Africa are younger than 50, reside in Gauteng and consume wine more frequently (daily). Their view of the price of Robertson wine is insignificant, although quality does seem to play a role, with those viewing the quality of Robertson wines as similar to those from other regions in the country displaying a lower WTP.

These results about the ethical wine tourist differ from what Roberts (1995) and Littrell and Dickson (1999) found, with no significant differences in WTP between male and female consumers. In terms of the age of ethical consumers, our research results confirm the findings of Anderson and Cunningham (1972), Roberts (1995) and De Pelsmacker et al. (2005), who all found younger consumers to be more socially responsible. However, we could not find support that only consumers in their late thirties to late forties are willing to pay more for socially responsible products, as Littrell and Dickson (1999) found. Contrary to previous research, we also could not find support that income influences stated WTP for more socially responsible wine, although it should be noted that Gauteng is moderately significant in some of the results and that it is also the province with the highest income per capita in the country.

In terms of the influence of price and quality on WTP for socially responsible products, Bird and Hughes (1997) distinguished three different classes of ethical consumers. The results from our research indicate that ethical wine consumers are less concerned about the price of the product and more about the quality. Therefore, ethical wine tourists in South Africa can rather be classified into the first and second categories identified by Bird and Hughes: consumers who are motivated by moral values and, secondly, those who are motivated by brand names and quality.

Finally, it is important to know the reasons why people are not willing to pay. The respondents who chose 'no' on both the initial and lower bid amounts offered to them (i.e. $19.69 \%$ of all respondents), had to rank the reasons according to importance, with the following choices offered to them:
- All wine farms should treat their workers fairly.

- Farmers must bear the cost of labour.

- It is not my responsibility.

- Other.

The most important reasons according to the respondents' ranking are, firstly, that they expect wine farmers to treat their workers fairly and, secondly, that farmers should bear the labour cost. The other reasons cited include that everyone is expected to abide by the labour laws.

A basic probit analysis of the respondents who are not willing to pay (no-no) reveals that respondents from the Western Cape have a higher probability of being unwilling to pay, while English-speaking respondents have a lower probability of choosing no-no. The results are, however, only significant at the $10 \%$ level.

\section{Findings and implications}

Based on the results, the first finding from this research is that $80.3 \%$ of all the wine tourists indicated a WTP an amount for more socially responsible wine. This is in line with research among European consumers, where it was found that $70 \%$ were willing to pay at least $10 \%$ on top of the standard price for a fair trade product (Basu \& Hicks 2008; Loureiro \& Lotade 2005). South African consumers are therefore more like European consumers in terms of their ethical consumption behaviour and less like American consumers, with only $20 \%$ of Americans willing to pay more for ethical products.

Secondly, the amount that South African wine tourists are willing to pay to ensure better living and working conditions for wine farm workers is R11.04. Given that the average bottle of wine in the Robertson valley sells for R65, this implies a premium of $17 \%$. This compares well with international studies, where PIPA (2000) found that $76 \%$ of consumers were willing to pay $25 \%$ more for products that were not manufactured using sweatshop labour, while a European study indicated that $70 \%$ of consumers were willing to pay at least $10 \%$ more for fair trade products. The first two findings imply that there is scope for the development of a 'socially responsible' label in the South African wine industry - similar to the fair trade label - and that South African wine consumers are willing to pay a premium on wine with such a label. The fair trade label is already available for some wines internationally, for example in the Netherlands.

Thirdly, concerning the characteristics of ethical consumers in South Africa, the study found the following sociodemographic variables to be significant: (1) age, with those younger than 50 willing to pay significantly more, and (2) origin, with wine tourists from South Africa's wealthiest province (Gauteng) willing to pay more. Contrary to other studies conducted, gender and income are not significant predictors of WTP for socially responsible wine in South Africa. For the future of ethical consumption in South Africa, these results are positive, since the country has a younger 
population distribution, and these consumers are more likely to pay for socially responsible products.

In addition to the socio-demographic variables, this research also included some behavioural variables and perceptions on quality and price to determine the extent to which they influence consumers' ethical consumption. We could find support that those who consume wine more frequently (i.e. daily and more than once a week) were willing to pay more, which may be an indication that those who consume wine as part of their lifestyle are more concerned about the sustainability of wine production in the country. This can be loosely linked to the teleological approach in the model of Hunt and Vittell $(1986,1993)$, although the current ethical buying behaviour models do not fully make provision for lifestyle and sustainability, which are aspects for future research.

Finally, we found wine consumers in South Africa to be less concerned about the price and more about the quality of the wine. Consumers who do not find the quality of the wine better than that from other regions are willing to pay significantly less to ensure better working and living conditions for wine farm workers. Therefore, we conclude that the ethical wine consumer typically falls in the first two categories identified by Bird and Hughes (1997), although it would be worthwhile to profile the different segments of ethical wine consumers in South Africa better - also an aspect for future research.

\section{Conclusion}

The purpose of this article was to determine wine tourists' WTP for improved working and living conditions for wine farm workers. The research was conducted among wine tourists at the 2017 Wacky Wine Festival in the Robertson valley in South Africa, which saw strike action in 2016 by wine farm labourers demanding better wages. Altogether 397 questionnaires were completed and a double-bounded dichotomous contingent valuation design was used to determine the wine tourists' WTP for more socially responsible wine.

This article makes a contribution to understanding ethical consumption behaviour among South African consumers, about which very little is currently known. In this context, South African consumers show similarities to European consumers in ethical consumer behaviour. This is encouraging since research shows that Europeans are the leaders in ethical consumer behaviour.

The research is the first attempt in the country to identify ethical consumers, as well as the reasons why people would not be willing to pay more for ethical goods. While international research mainly identifies older people as more 'ethical', the South African situation seems to be different, with younger people being more concerned about ethical aspects.
The research shows that there is scope for introducing some 'ethical' brand or label in the South African wine industry, and that consumers would be willing to pay more for wines that certify fair treatment of workers involved in their production.

\section{Acknowledgements}

The authors would like to thank Beatrix Galloway of the Wacky Wine Festival, all the respondents who completed the questionnaires, and the anonymous reviewers for their constructive comments.

\section{Competing interests}

The authors declare that they have no financial or personal relationships that may have inappropriately influenced them in writing this article.

\section{Authors' contribution}

A.S. and M.S. co-developed, conceptualised and executed the research.

\section{References}

Anderson, T.W. \& Cunningham, W.H., 1972, 'The socially conscious consumer', Journa of Marketing 36, 23-31. https://doi.org/10.1177/002224297203600305

Arnot, C., Boxall, P.C. \& Cash, S.B., 2006, 'Do ethical consumers care about price? A revealed preference analysis of fair trade coffee purchases', Canadian Journal of Agricultural Economics 54(4), 555-565. https://doi.org/10.1111/j.1744-7976. 2006.00066.x

Basu, A.K. \& Hicks, R.L., 2008, 'Label performance and the willingness to pay for fair trade coffee: A cross-national perspective', International Journal of Consumer Studies 32(5), 470-478. https://doi.org/10.1111/j.1470-6431.2008.00715.x

Bird, K. \& Hughes, D.R., 1997, 'Ethical consumerism: The case of "fairly-traded" coffee', Business Ethics: A European Review 6(3), 159-167. https://doi.org/10.1111/14678608.00063

Bureau for Food and Agricultural Policy (BFAP), 2015, 'Farm-worker sectoral determination: An analysis of agricultural wages in South Africa 2015', BFAP, Pretoria.

Cowe, R. \& Williams, S., 2000, Who are the ethical consumers, Booklet for Cooperative Bank, Manchester.

De Pelsmacker, P., Driessen, L. \& Rayp, G., 2005, 'Do consumers care about ethics? Willingness-to-pay for fair trade coffee', Journal of Consumer Affairs 39(2), 361-383. https://doi.org/10.1111/j.1745-6606.2005.00019.x

De Pelsmacker, P. \& Janssens, W., 2007, 'A model for fair trade buying behaviour: The role perceived quantity and quality of information and product-specific attitudes', Journal of Business Ethics 75(4), 361-380. https://doi.org/10.1007/s10551-0069259-2

Dickson, M.A., 2001, 'Utility of no-sweat labels for apparel consumers: Profiling labe users and predicting their purchases', Journal of Consumer Affairs 35(1), 96-119. https://doi.org/10.1111/j.1745-6606.2001.tb00104.x

Didier, T. \& Lucie, S., 2008, 'Measuring consumer's willingness to pay for organic and fair trade products', International Journal of Consumer Studies 32(5), 479-490. https://doi.org/10.1111/j.1470-6431.2008.00714.x

Doane, D., 2001, Taking flight: The rapid growth of ethical consumerism, New Economics Foundation, London.

Elliott, K. \& Freeman, R.B., 2003, Can labor standards improve under globalization? Institute for International Economics, Washington, DC.

Fairtrade Labelling Organizations International (FLO), 2017, Fairtrade International, viewed 15 January 2018, from http://www.fairtrade.net

Fourie, J., 2014, Subverting the standard view of the Cape economy: Robert Ross's cliometric contribution and the work it inspired, Stellenbosch Economic Working Papers 16/14, Stellenbosch University, Stellenbosch.

Fourie, J. \& Von Fintel, D., 2011, 'A history with evidence: Income inequality in the Dutch Cape Colony', Economic History of Developing Regions 26(1), 16-48. https://doi.org/10.1080/20780389.2011.582990

Fourie, J. \& Von Fintel, D., 2014, 'Settler skills and colonial development: The Huguenot wine-makers in eighteenth-century Dutch South Africa', Economic History Review 67(4), 932-963. https://doi.org/10.1111/1468-0289.12033

Fritzsche, D.J., 1995, 'Personal values: Potential keys to ethical decision making', Journal of Business Ethics 14(11), 909-922. https://doi.org/10.1007/BF00882069 
Goldblatt, A., 2010, Agriculture: Facts \& trends, South Africa, viewed 18 January 2018 from http://awsassets.wwf.org.za/downloads/facts_brochure_mockup_04_b.pdf

Harris, J.M. \& Roach, B., 2009, The economics of global climate change, Global Development and Environmental Institute, Tufts University, Medford, MA.

Hicks, R.L., 2006, 'Performance-based labeling', in U. Grote, A.K. Basu \& N.H. Chau (eds.), New frontiers in eco and social labeling, pp. 37-38, Physica-Verlag, Springe Publishing, Berlin.

Hines, C. \& Ames, A., 2000, Ethical consumerism (a research study conducted for the co-operative bank), Market \& Opinion Research International (MORI), London.

Hunt, S.D. \& Vitell, S., 1986, 'A general theory of marketing ethics', Journal of Macro Marketing 6(1), 5-16. https://doi.org/10.1177/027614678600600103

Hunt, S.D. \& Vitell, S., 1993, 'The general theory of marketing ethics: A retrospective and revision', in N.C. Smith \& J.A. Quelch (eds.), Ethics in marketing, pp. 775-784, Irwin, Homewood, IL.

Idea Consult, 2002, Effectenstudie en opiniepeiling over Eerlijke Handel in België, Research report for the Belgian Ministry of Foreign Affairs and International Cooperation, Brussels.

Kavonic, D., 2017, South African wine regions \& routes, viewed 10 January 2018, from http://www.capetownmagazine.com/things-to-do-cape-town/south-africanwine-regions-and-routes/15_52_55869

Littrell, M. \& Dickson, M., 1999, Social responsibility in the global market. Fair trade of cultural products, Sage Publications Inc., Thousand Oaks, CA.

Lopez-Feldman, A., 2012, Introduction to contingent valuation in Stata. Munich Personal RePEC Archive. MRPA Paper No. 41018, viewed 24 July 2016, from http://mpra.ub.uni-muenchen.de/41018/

Loureiro, M.L. \& Lotade, J., 2005, 'Do fair trade and eco-labels in coffee wake up the consumer conscience', Ecological Economics 53(1), 129-138. https://doi. org/10.1016/j.ecolecon.2004.11.002

Makumbirofa, S. \& Saayman, A., 2017, 'Willingness to pay for common pool resources: A comparison between Ponta do Ouro and Portofino', paper presented at the 6th IATE Conference, Rimini, Italy, 21-23 June.

Market \& Opinion Research International (MORI), 2000, The first ever European survey of consumers' attitudes towards corporate social responsibility, Research report for CSR Europe, MORI, London.

Moore, G., 2004, 'The fair trade movement: Parameters, issues and future research' Journal of Business Ethics 53(1), 73-86. https://doi.org/10.1023/B:BUSI.00000 39400.57827.c3

Program on International Policy Attitudes (PIPA), 2000, Americans on globalization viewed 15 January 2018, from http://www.pipa.org/publication.php
Redfern, A. \& Snedker, P., 2002, Creating market opportunities for small enterprises: Experiences of the fair trade movement, ILO, Geneva.

Roberts, J.A., 1995, 'Profiling levels of socially responsible consumer behaviour: A cluster analytic approach and its implications for marketing', Journal of Marketing - Theory and Practice 3(4), 97-117. https://doi.org/10.1080/1069667 9.1995.11501709

Saayman, M., 2017, 'Invited speech at the round table on blue growth and tourism', paper presented at the 6th IATE Conference, Rimini, Italy, 21-23 June.

Shaw, D. \& Clarke, I., 1999, 'Belief formation in ethical consumer groups: An exploratory study', Marketing Intelligence \& Planning 17(2), 109-119. https://doi org/10.1108/02634509910260968

Shaw, D. \& Shiu, E., 2002, 'The role of ethical obligation and self-identity in ethical consumer choice', International Journal of Consumer Studies 26(2), 109-116. https://doi.org/10.1046/j.1470-6431.2002.00214.x

Sikula, A. \& Costa, A.D., 1994, 'Are women more ethical than men', Journal of Business Ethics 13(11), 859-871. https://doi.org/10.1007/BF00871700

Steinrücken, T. \& Jaenichen, S., 2007, 'The fair trade idea: Towards an economics of social labels', Journal of Consumer Policy 30(3), 201-217. https://doi.org/10.1007/ s10603-007-9034-5

Tietenberg, T. \& Lewis, L., 2012, Environmental and natural resource economics, 9th edn., Pearson, Boston, MA.

Tsalikis, J. \& Oritz-Buonafina, M., 1990, 'Ethical beliefs differences of males and females', Journal of Business Ethics 9(6), 509-517. https://doi.org/10.1007/BF00382844

Van den Broeck, G., Vlaeminck, P., Raymaekers, K., Vande Velde, K., Vranken, L. \& Maertens, M., 2017, 'Rice farmers' preferences for fairtrade contracting in Benin: Evidence from a discrete choice experiment', Journal of Cleaner Production 165, 846-854. https://doi.org/10.1016/j.jclepro.2017.07.128

Vitell, S.J., Singhapakdi, A. \& Thomas, J., 2001, 'Consumer ethics: An application and empirical testing of the Hunt-Vitell theory of ethics', Journal of Consumer Marketing 18(2), 153-178. https://doi.org/10.1108/07363760110386018

Wines of South Africa, 2018, Wine growing areas, viewed 10 January 2018, from http://www.wosa.co.za/The-Industry/Winegrowing-Areas/Winelands-of-SouthAfrica/

World Fair Trade Organization (WFTO), 2017a, Definition of fair trade, viewed 15 January 2018, from https://wfto.com/fair-trade/definition-fair-trade

World Fair Trade Organization (WFTO), 2017b, 10 principles of fair trade, viewed 20 January 2018, from https://wfto.com/fair-trade/10-principles-fair-trade

Wright, S. \& McCrea, D. (eds.), 2007, The handbook of organic and fair trade food marketing, Blackwell, Oxford. 